ISSN 1392-3196 / e-ISSN 2335-8947

Zemdirbyste-Agriculture, vol. 104, No. 1 (2017), p. 9-14

DOI 10.13080/z-a.2017.104.002

\title{
Degradation capacity of humic acids-degrading bacteria on humic acids extracted from arable soil
}

\author{
Donglei FU ${ }^{1,2}$, Mengyun LIU', Qingrui CHANG ${ }^{1}$, Liwen LIU ${ }^{1}$, Aihua LV ${ }^{2}$ \\ ${ }^{1}$ College of Natural Resources and Environment, Northwest A\&F University \\ No. 3 Taicheng, Yangling 712100, Shaanxi, PR China \\ E-mail: 1my471993@163.com \\ ${ }^{2}$ Urumqi Environmental Monitoring Center \\ No. 728 Siping, Urumqi 830000, the Xinjiang Uygur Autonomous Region, PR China
}

\begin{abstract}
The aim of the present experiment was to determine the degradation level of humic acids (HA) extraced from arable soil by three selected strains. A short-term experiment was carried out in 2014 at State Key Laboratory of Crop Stress Biology for Arid Areas, Northwest A\&F University. HA was extracted from arable soil and was used as the sole carbon (C) and nitrogen (N) source in solid culture medium. Three soil HA-degrading strains Bacillus licheniformis (strain 1), Microbacterium resistens (strain 2) and Stenotrophomonas maltophilia (strain 3), were chosen to further investigate their individual and combined effects on the $\mathrm{C}$ degradation rate and structural properties of humic acids in the medium. The experiment included seven treatments: T1, T2, T3, T1+T2, T1+T3, $\mathrm{T} 2+\mathrm{T} 3$ and $\mathrm{T} 1+\mathrm{T} 2+\mathrm{T} 3$.

Results showed that the total colony-forming units (CFU) of S. maltophilia (strain 3) showed higher amount in the treatments it was associated with. Carbon respiration (CR) and microbial biomass carbon (MBC) in various treatments varied between 4.04 (T2) to 12.13 (T2+T3) $\mathrm{mg} \mathrm{dish}^{-1}$ and 1.32 (T2) to 4.96 (T3) $\mathrm{mg} \mathrm{dish}^{-1}$, in terms of the $\mathrm{C}$ degradation rates in humic acids, the sum of $\mathrm{CR}$ and $\mathrm{MBC}$, followed the trend $\mathrm{T} 2+\mathrm{T} 3(52.05 \%)>\mathrm{T} 1+\mathrm{T} 3(49.29 \%)$ $>\mathrm{T} 1(44.25 \%)>\mathrm{T} 3(40.61 \%)>\mathrm{T} 1+\mathrm{T} 2(38.39 \%)>\mathrm{T} 1+\mathrm{T} 2+\mathrm{T} 3(37.09 \%)>\mathrm{T} 2(18.91 \%)$. Infrared spectroscopy revealed that medium of all treatments resulted in higher levels of carbohydrate, aliphatic compounds, alcohols and nitrogenous substances after degradation process. T1 exhibited the lowest aromatic $\mathrm{C}$ content compared with the content before degradation, while that in $\mathrm{T} 1+\mathrm{T} 2+\mathrm{T} 3$ was the highest. Thus, B. licheniformis (strain 1) might have a relatively strong degradation capacity for aromatic $\mathrm{C}$.
\end{abstract}

Key words: carbon degradation rate, colony-forming unit, decomposing bacteria, humic acids, structural properties.

\section{Introduction}

The global soil contains $2.4 \times 10^{12} \mathrm{t}$ of humic substances, accounting for approximately $67 \%$ of the organic carbon (C) reserved in the biosphere. Therefore, the soil environment and global change are profoundly impacted by soil organic carbon (SOC); mainly consisting of humus C. Humic acids (HA) are a component of soil humus with an intermediate molecular weight, a complex structure and relatively active chemical and biological properties. The functional group structure and elemental composition of HA vary with different vegetation types, land-use patterns and extraction methods (Tatzber et al., 2007; Yanagi et al., 2008; Prentice, Webb, 2010). It has been found that traditional cultivation patterns are unfavourable for SOC sequestration and transformation (Eaton, Lawrence, 2009; Acharya et al., 2012).

Soil microbial biomass refers to the total biomass of organisms with a volume $<5.000 \mu^{3}$ (excluding live plants) in the soil, mainly including bacteria, fungi, algae and protozoa (Rinna et al., 2002; Ravindran, Yang, 2015). The direct effect of soil microorganisms on the

transformation of organic matter is a critical driving force and controlling factor in the $\mathrm{C}$ cycle (Rinna et al., 2002). Therefore, research on the soil C cycle is essential to study microbially mediated ecological processes in the soil. HA shows a close relationship with soil microorganisms. Aliphatic $\mathrm{C}$ and small-molecule carbohydrates contained in the HA structure as well as $\mathrm{C}$ and nitrogen $(\mathrm{N})$ in the side chains of aromatic rings provide $\mathrm{C}$ and $\mathrm{N}$ sources for microbial metabolism (Chistyakov et al., 2013). The HA degradation rate is affected by the functional group composition of the HA structure (Guo et al., 2013).

Progress has been made in research on the microbial degradation of HA in other countries. Monib et al. (1981) investigated the level and characteristics of HAdegradation by Streptomyces. Korniłłowicz-Kowalska et al. (2008) found that an anamorphic Bjerkandera adusta isolated from soil was capable of decolorizing $\mathrm{HA}$, and the decolorization degree was related partially to adsorption by fungal mycelium. Huang et al. (2009) investigated changes of fluorescence spectroscopy

Please use the following format when citing the article:

Fu D., Liu M., Chang Q., Liu L., Lv A. 2017. Degradation capacity of humic acids-degrading bacteria on humic acids extracted from arable soil. Zemdirbyste-Agriculture, 104 (1): 9-14 DOI 10.13080/z-a.2017.104.002 
characteristics of HA influenced by Phanerochaete chrysosporium (a kind of white-rot fungus) during different phases of agricultural waste composting. Study of Badis et al. (2010) showed that the growth of three active streptomyces from 19 actinomycetes strains was poor in liquid medium containing natural humic acids as $\mathrm{C}$ and $\mathrm{N}$ sources when glucose was absent in the medium. Rocker et al. (2012) found the characteristics of HA-degrading microorganisms and associated enzymatic activity played important roles in HA decomposition. Park and Kim (2013) suggested that Bacillus showed a high capacity to degrade HA. However, these researches have mainly focused on the level and characteristics of HA degradation by HA-degrading microorganisms, while detailed quantification of the degradation level of HA has been non-systematic. In particular, studies on the degradation of HA during the cultivation of Heilu soil, a typical soil found on the Loess Plateau in northwest China, are still lacking.

In a previous study, we isolated five soil HA decomposition bacteria from five types of vegetation, including Chinese pine, black locust, sea-buckthorn, mixed forest and arable land (Fu et al., 2014). These vegetation types, except for arable land, are seen as representative vegetation in the Three-North Forest Shelterbelt Program to implement the ecological restoration plan in northwest China. The arable land is presenting the characteristics of mosaic distribution among vegetation types in the study area, thus, more attention should be paid to this land use type, whose soil carbon pool is influenced substantially by human intervention such as tillage, fertilization and abandonment. In this study, three bacteria Bacillus licheniformis, Microbacterium resistens and Stenotrophomonas maltophilia (both individual and combination) were selected to further investigate their HA degradation characteristics in arable soil on the basis of their growth performance and microbial biomass in HA solid medium. Our present work differs from previous researches in that that arable soil HA was used as the sole $\mathrm{C}$ and $\mathrm{N}$ source in the culture medium, whereas in other studies individual substances were often used as supplementary C (e.g., glucose) (Kontchou, Blondeau, 1992; Tikhonov et al., 2010) and N (e.g., yeast extract powder, ammonium tartrate and ammonium nitrate, $\mathrm{NH}_{4} \mathrm{NO}_{3}$ ) sources in the culture medium. Combined analysis adopting infrared (IR) spectroscopy was to determine the effect of the HA-degrading bacteria on the HA degradation level and structural characteristics during the degradation process.

\section{Materials and methods}

Separation of HA-degrading bacteria. In our previous study (Fu et al., 2014), soil HA extracted from different vegetation types was used as the sole $\mathrm{C}$ and $\mathrm{N}$ source to prepare HA solid medium. The medium contained $0.2300 \mathrm{~g}$ of $\mathrm{HA}, 0.25 \mathrm{~g}$ of $\mathrm{NaCl}, 1.00 \mathrm{~g}$ of agar and $50.0 \mathrm{~mL}$ of distilled $\mathrm{H}_{2} \mathrm{O}$. The medium was aseptically dispensed into $90-\mathrm{mm}$ diameter Petri dishes (15.0 mL each). Soil samples (10.00 g each) were weighed into $250-\mathrm{mL}$ triangular flasks, followed by the addition of $100 \mathrm{~mL}$ of sterile distilled water. The mixture was oscillated in a shaker for $30 \mathrm{~min}$, and $100 \mu \mathrm{L}$ of the supernatant was then spread on HA agar plates. Once the colonies became distinct on the medium, the strains were separated and purified. Five HA-degrading bacterial strains related to Bacillus licheniformis, Microbacterium resistens, Stenotrophomonas maltophilia, Rhizobium nepotum and Streptomyces azureus were obtained according to $16 \mathrm{~s}$ rRNA sequence analysis.

Experimental bacteria selection. The present study, with the purpose of examining the degradation level of HA, was a further work on the previous research. The experiment was carried out at State Key Laboratory of Crop Stress Biology for Arid Areas, Northwest A\&F University in 2014. Soil sample preparation was detailed in a previous study (Fu et al., 2014). HA was extracted by $\mathrm{NaOH}$ and $\mathrm{Na}_{4} \mathrm{P}_{2} \mathrm{O}_{7}$ solution, concrete steps were carried out according to Tatzber et al. (2007). The selection criteria for the HA-degrading bacteria were as follows: accounting for a larger proportion of the total colony count and exhibiting good growth performance. Three HA-degrading bacteria were selected accordingly: Bacillus licheniformis, Microbacterium resistens and Stenotrophomonas maltophilia, and the three strains were coded 1, 2 and 3, respectively. Seven treatments (T1, T2, T3, T1+T2, T1+T3, T2+T3 and T1+T2+T3) were included to investigate the $\mathrm{C}$ degradation of $\mathrm{HA}$ extracted from arable soil by the three bacteria both individually and jointly. Hereafter T1, T2 and T3 refer to the single-colony treatments, and T1+T2, T1+T3, T2+T3 and $\mathrm{T} 1+\mathrm{T} 2+\mathrm{T} 3$ refer to the combination treatments.

Inoculation time selection. Arable soil HA solid medium contained $0.2300 \mathrm{~g}$ of $\mathrm{HA}, 0.25 \mathrm{~g}$ of $\mathrm{NaCl}$, $1.00 \mathrm{~g}$ of agar and $50.0 \mathrm{~mL}$ of distilled $\mathrm{H}_{2} \mathrm{O}$, with the $\mathrm{pH}$ adjusted to 7.3 . Following steam sterilization $(0.1 \mathrm{MPa}$, $30 \mathrm{~min}$ ), the medium was slightly cooled and aseptically dispensed into $90-\mathrm{mm}$ diameter Petri dishes $(15.0 \mathrm{~mL}$ each). Each Petri dish contained $28.34 \mathrm{mg}$ of C. Each treatment was repeated four times. The arable soil HA contained $41.08 \% \mathrm{C}$ and $4.32 \% \mathrm{~N}$. An inoculation loop was used to transfer a small amount of the purified colonies from the three strains to sterile tubes containing $10.0 \mathrm{~mL}$ of HA broth (with the same composition indicated above, excluding agar), respectively. The tubes were then cultured in oscillated water bath at $37^{\circ} \mathrm{C}$, and $15-\mu \mathrm{L}$ broth culture samples were collected at $24-\mathrm{h}$ intervals. The culture samples were diluted in $150-\mathrm{mL}$ flasks to a constant volume and mixed thoroughly. Then, $100-\mu \mathrm{L}$ from 150 -mL flasks were spread uniformly on HA agar plates. The number of HA-degrading bacterial colonies on HA medium was counted and recorded as colony-forming units per dish $\left(\mathrm{CFU} \mathrm{dish}^{-1}\right)$. When the CFU stabilized (day 5 in Fig. 1), $15.0 \mu \mathrm{L}$ of each HA broth culture was obtained and diluted to a constant volume in $150-\mathrm{mL}$ flasks. The dilutions were thoroughly mixed, and $100 \mu \mathrm{L}$ aliquots were spread on HA agar plates (the same composition with HA solid medium mentioned above) for the T1, T2 and T3 treatments. For the T1+T2 treatment, $7.5 \mu \mathrm{L}$ was collected from equal volume of HA broth strain 1 and strain 2 and diluted to a constant volume in $150-\mathrm{mL}$ flasks. The rest of the procedure was identical to that performed for $\mathrm{T} 1$, and the same procedure was applied for the $\mathrm{T} 2+\mathrm{T} 3$ and $\mathrm{T} 1+\mathrm{T} 3$ treatments. For the $\mathrm{T} 1+\mathrm{T} 2+\mathrm{T} 3$ treatment, a $5.0-\mu \mathrm{L}$ aliquot was collected from the HA broth cultures of the same volume of the three HA-degrading bacteria and processed via the same procedure described above. The broth cultures were diluted $1 \times 10^{4}$-fold, and the initial concentrations of strain 1, strain 2 and strain 3 were about $2.0 \times 10^{5}, 2.9 \times$ $10^{5}$ and $6.7 \times 10^{5} \mathrm{~mL}^{-1}$ (day 1 in Fig. 1).

Measurement of experimental indices. Carbon respiration (CR) was measured as follows: a number of 90-mm diameter Petri dishes were packed together, and their connections were sealed using acacia. The whole pack of Petri dishes was then wrapped with sealing film to 


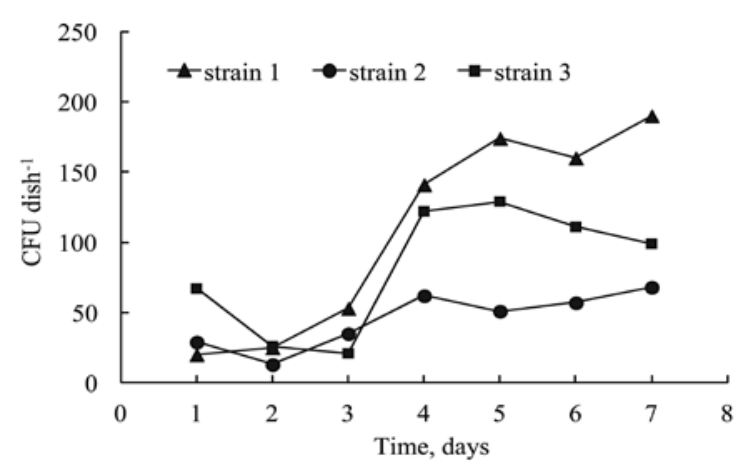

Note. CFU of different treatments varies in small ranges during the first 3 days, and it stabilizes on day 5 with the amount of 174 (strain 1-Bacillus licheniformis), 51 (strain 2-Microbacterium resistens) and 129 (strain 3 - Stenotrophomonas maltophilia), respectively.

Figure 1. Changes of colony-forming units (CFU) during incubating

ensure air tightness. The solid HA medium was adhered to the top of the agar plates. Carbon dioxide $\left(\mathrm{CO}_{2}\right)$ gas produced via the respiration of HA-degrading bacteria was collected using $10 \mathrm{~mL}$ of $1.0 \mathrm{~mol} \mathrm{~L}^{-1} \mathrm{NaOH}$ and titrated with approximately $0.5 \mathrm{~mol} \mathrm{~L}^{-1} \mathrm{HCl}$ every $24 \mathrm{~h}$ (the exact concentration of the $\mathrm{HCl}$ solution was calibrated with $\mathrm{Na}_{2} \mathrm{~B}_{4} \mathrm{O}_{7} \times 10 \mathrm{H}_{2} \mathrm{O}$ ). The plates were then incubated at $28^{\circ} \mathrm{C}$ for 14 days. The medium was supplemented with sterile air for $3 \mathrm{~min}$ during the titration process, and the loss of $\mathrm{CO}_{2}$ during the titration period was calculated by 30 min of $\mathrm{CO}^{2}$ absorption. CR refers to the amount of $\mathrm{C}$ consumed by HA-degrading bacteria through respiration. The calculation of CR was as follows (Yim et al., 2002):

$\mathrm{CR}=6 \mathrm{~W}\left(2 \mathrm{~V}_{1}-\mathrm{V}_{2}-\mathrm{V}_{0}\right)$

where $\mathrm{V}_{1}, \mathrm{~V}_{2}$ and $\mathrm{V}_{0}$ represent the blank control, the 3-min $\mathrm{CO}_{2}$ loss, the $\mathrm{HCl}$ volume consumed through titration $(\mathrm{mL})$, respectively; $\mathrm{W}-$ the concentration of $\mathrm{HCl}\left(\mathrm{mol} \mathrm{L}^{-1}\right), 6$ - the conversion factor.

At the end of the incubation period, a typical repetition was chosen to pick out all of the visible colonies. Extraction of HA from the medium was performed using a mixture of $\mathrm{NaOH}$ and $\mathrm{Na}_{4} \mathrm{P}_{2} \mathrm{O}_{7}$ solutions $\left(0.1 \mathrm{~mol} \mathrm{~L}^{-1}\right.$ each). First, $40 \mathrm{~mL}$ of the extraction solution was used to slowly wash the HA agar and then filtered through a 0.45$\mu \mathrm{m}$ filter membrane. The washing lasted for $4 \mathrm{~h}$, with the aim of intercepting the remaining HA-degrading bacteria by the filter membrane and eliminating their impact on IR spectroscopy. Thereafter, the washed HA agar was soaked in $100 \mathrm{~mL}$ of extraction solution five times (the medium had become transparent, and extraction was basically completed through four washes). The soaking time was $24 \mathrm{~h}$, and all of the extraction solutions were subsequently transferred to a $150-\mathrm{mL}$ volumetric flask for IR spectral analysis. The detailed two-step extraction procedure was described by Tatzber et al. (2007). The remaining three replications were used to measure microbial biomass carbon (MBC).

$\mathrm{MBC}$ refers to the amount of $\mathrm{C}$ in HA-degrading bacteria. MBC was measured via the fumigation culture method and converted to the unit of Petri dishes as follows:

$\mathrm{MBC}=\left(\mathrm{M}_{1}-\mathrm{M}_{0}\right) / \mathrm{k}$

where $M_{1}$ and $M_{0}$ are the amounts of $\mathrm{CO}_{2}$ released from the fumigated and non-fumigated media $\left(\mathrm{mg}\right.$ dish $\left.^{-1}\right)$, respectively, $\mathrm{k}-\mathrm{a}$ constant (generally 0.411).
Total degradation quantities are the sum of $\mathrm{CR}$ and $\mathrm{MBC}$, and carbon degradation rate is the ratio between total degradation amount and carbon content (28.34 mg for each dish).

Analytical instrument and statistical methods. The percentage contents of $\mathrm{C}$ and $\mathrm{N}$ in HA were determined using an elemental analyzer AutAnalyel ("Bran Luebbe", Germany). A bacterial CFU was performed via the plate count method. Infrared (IR) spectral analysis was carried out using a Tensor 27 Fourier-transform infrared spectrometer ("Bruker", Germany). Data processing was performed using EXCEL 2013. The IR absorption peak area was calculated using OPUS 6.5. Analysis of variance was performed using $S A S 8.1$.

\section{Results and discussion}

Quantitative characteristics of humic acids (HA)-degrading bacteria. The CFU of HA-degrading bacteria showed greater variations between the singlecolony treatments, with the amounts in T1 and T2 corresponding to $53.95 \%$ and $26.98 \%$ of the amounts in $\mathrm{T} 3$, respectively. Among the combination treatments, the bacterial CFU followed the trend of $\mathrm{T} 1+\mathrm{T} 3>\mathrm{T} 1+\mathrm{T} 2+\mathrm{T} 3$ $>\mathrm{T} 2+\mathrm{T} 3>\mathrm{T} 1+\mathrm{T} 2$. The CFU of $S$. maltophilia (strain 3) was the highest in combination treatments, accounting for $86.92,83.23$ and $82.52 \%$ of total CFU in T1+T3, T2+T3 and $\mathrm{T} 1+\mathrm{T} 2+\mathrm{T} 3$, respectively. Different bacterial species exhibited varying capacities for HA degradation (Yanagi et al., 2008), which are closely associated with their adaptability to HA. In the present study, S. maltophilia (strain 3) remained higher CFU in HA substrate among the various single-colony and combination treatments and became the dominant species, indicating its suitability in the medium. The CFU of combination treatments containing $B$. licheniformis (strain 1) were relatively stable, as strain 1 showed a direct relationship with the decomposition of organic matter and could therefore accelerate the conversion of organic nutrients in the soil (Huang et al., 2007). The two strains displayed distinct colony morphology, suggesting that they were able to achieve niche separation, thus preventing intense competition between different populations. Additionally, a previous study (Li et al., 2012) showed that $S$. maltophilia (strain 3) could coexist with other bacteria and enhance their activity. Besides, $M$. resistens (strain 2) was capable of utilizing HA to a lesser extent for its poor growth in $\mathrm{T} 1+\mathrm{T} 2$ and $\mathrm{T} 1+\mathrm{T} 2+\mathrm{T} 3$, representing only $25.00 \%$ and $1.94 \%$ of the total CFU (Table 1).

Carbon $(C)$ degradation of humic acids $(H A)$. Carbon respiration (CR) showed significant differences $(P<0.05)$ between various treatments and was generally higher in the combination treatments than in the single-

Table 1. Colony-forming units (CFU) in various treatments

\begin{tabular}{ccccc}
\hline Treatment & Strain 1 & Strain 2 & Strain 3 & Total CFU \\
\hline T1 & $116 \pm 8$ & - & - & $116 \pm 8$ \\
T2 & - & $58 \pm 7$ & - & $58 \pm 7$ \\
T3 & - & - & $215 \pm 17$ & $215 \pm 17$ \\
T1+T2 & $42 \pm 6$ & $14 \pm 3$ & - & $56 \pm 3$ \\
T1+T3 & $34 \pm 4$ & - & $226 \pm 15$ & $260 \pm 12$ \\
T2+T3 & - & $26 \pm 4$ & $129 \pm 12$ & $155 \pm 13$ \\
T1+T2+T3 & $32 \pm 4$ & $4 \pm 2$ & $170 \pm 17$ & $206 \pm 18$ \\
\hline
\end{tabular}

Notes. Strain 1 - Bacillus licheniformis, strain 2 - Microbacterium resistens, strain 3 - Stenotrophomonas maltophilia. The values are represented as mean \pm standard deviation (SD) calculated by four replicate measurements in each treatment. Integers remain only in the table. 
colony treatments. The highest $\mathrm{CR}$ occurred in $\mathrm{T} 2+\mathrm{T} 3$ and T1+T3, containing S. maltophilia (strain 3). T1 exhibited the highest respiration in the single-colony treatments, which was $105.69 \%$ and $26.87 \%$ higher than $\mathrm{T} 2$ and T3. MBC was directly related to CFU. There were significant differences in MBC between T1, T3, T1+T3, $\mathrm{T} 2+\mathrm{T} 3, \mathrm{~T} 1+\mathrm{T} 2+\mathrm{T} 3$ and $\mathrm{T} 2(P<0.05)$. B. licheniformis (strain 1) and S. maltophilia (strain 3) clearly showed a higher $\mathrm{C}$ sequestration capacity, because significantly higher levels of $\mathrm{MBC}$ were detected in $\mathrm{T} 1, \mathrm{~T} 3$ and $\mathrm{T} 1+\mathrm{T} 3$ compared with the other treatments (Table 2). In terms of the $\mathrm{C}$ degradation rates in the various treatments it ranged from $18.91 \%$ to $52.05 \%$, with the highest in $\mathrm{T} 2+\mathrm{T} 3$ and the lowest in T2. These values were close to the HA degradation rates by HA-degrading bacteria observed in arable soil, ranging from $17.30-56.00 \%$ (Filip, Kubát, 2003; Filip, Tesařová, 2004).

Table 2. Carbon (C) decomposing state in humic acids (HA)

\begin{tabular}{ccccc}
\hline Treatment & $\begin{array}{c}\text { Carbon } \\
\text { respiration } \\
\text { mg dish }^{-1}\end{array}$ & $\begin{array}{c}\text { Microbial } \\
\text { biomass } \\
\text { carbon } \\
\text { mg dish }^{-1}\end{array}$ & Total degradation amount & Carbon degradation rate \\
\hline T2+T3 & $12.13 \mathrm{a}$ & $2.62 \mathrm{~d}$ & $14.75 \mathrm{a}$ & $52.05 \mathrm{a}$ \\
$\mathrm{T} 1+\mathrm{T} 3$ & $10.45 \mathrm{~b}$ & $3.52 \mathrm{c}$ & $13.97 \mathrm{a}$ & $49.29 \mathrm{a}$ \\
$\mathrm{T} 1+\mathrm{T} 2$ & $9.22 \mathrm{c}$ & $1.66 \mathrm{ef}$ & $10.88 \mathrm{~cd}$ & $38.39 \mathrm{~cd}$ \\
T1+T2+T3 & $8.44 \mathrm{~d}$ & $2.07 \mathrm{e}$ & $10.51 \mathrm{~d}$ & $37.09 \mathrm{~d}$ \\
$\mathrm{~T} 1$ & $8.31 \mathrm{~d}$ & $4.23 \mathrm{~b}$ & $12.54 \mathrm{~b}$ & $44.25 \mathrm{~b}$ \\
T3 & $6.55 \mathrm{e}$ & $4.96 \mathrm{a}$ & $11.51 \mathrm{c}$ & $40.61 \mathrm{c}$ \\
T2 & $4.04 \mathrm{f}$ & $1.32 \mathrm{f}$ & $5.36 \mathrm{e}$ & $18.91 \mathrm{e}$ \\
\hline
\end{tabular}

Notes. Total degradation amount is the sum of $\mathrm{CR}$ and $\mathrm{MBC}$, and carbon degradation rate is the ratio between total degradation amount and carbon content ( $28.34 \mathrm{mg}$ for each dish). Values of each treatment are average of total quantities of four replicate measurements after decomposing. Means followed by lowercase letters are significantly different at $P<0.05$.

Infrared (IR) spectral features after $\mathrm{HA}$ degradation. IR spectra reflect the information on the molecular structure and functional groups of complex compounds (Baglieri et al., 2007). The presence of certain functional groups and their relative contents in HA can be determined based on the position and peak intensity of the absorption peak. The assignment of the IR spectra of HA was performed according to the literature (Amir et al., 2010). The IR spectral analysis (Fig. 3) showed that the major absorption peaks occurred at $1045 \mathrm{~cm}^{-1} \quad(\mathrm{C}-\mathrm{O}$ stretching of polysaccharides compounds), $1075 \mathrm{~cm}^{-1}$ (C-OH stretching of alcohols), $1151 \mathrm{~cm}^{-1}$ (asymmetric stretching vibrations of ether bond $\mathrm{C}-\mathrm{O}-\mathrm{C}$ in ether bonds in aliphatic compounds and aliphatic rings), $1375 \mathrm{~cm}^{-1}$ (C-N stretching and $\mathrm{N}-\mathrm{H}$ bend), $1637 \mathrm{~cm}^{-1}(\mathrm{C}=\mathrm{C}$ stretching vibration of aromatic compounds) and $3340 \mathrm{~cm}^{-1}$ (O-H stretching). Compared with those observed before degradation, the spectral shapes corresponding to the various treatments presented

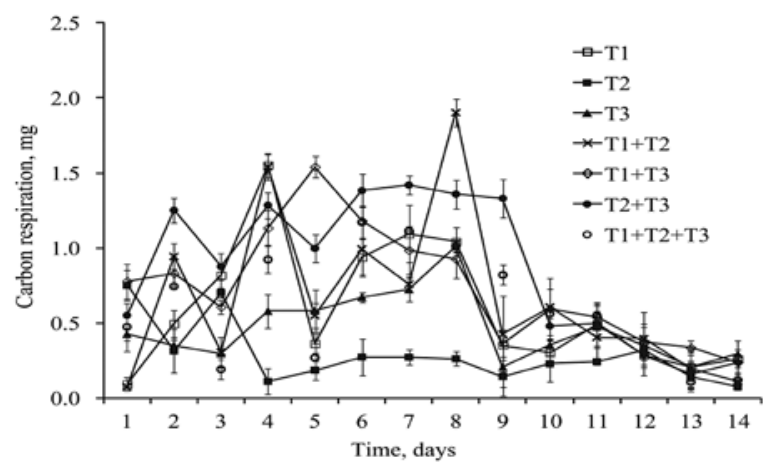

Note. Values are presented as mean \pm standard deviation (SD).

Figure 2. Carbon respiration (CR) dynamics of different treatments during incubating

certain changes. However, the similarity of the spectral shapes between the various treatments indicated that the structure and functional group composition of the HA degradation products were generally consistent. According to the absorption peaks, the structural units of HA after degradation included mainly polysaccharides, alcohols, nitrogenous substances, aliphatic and aromatic compounds and hydroxyl.

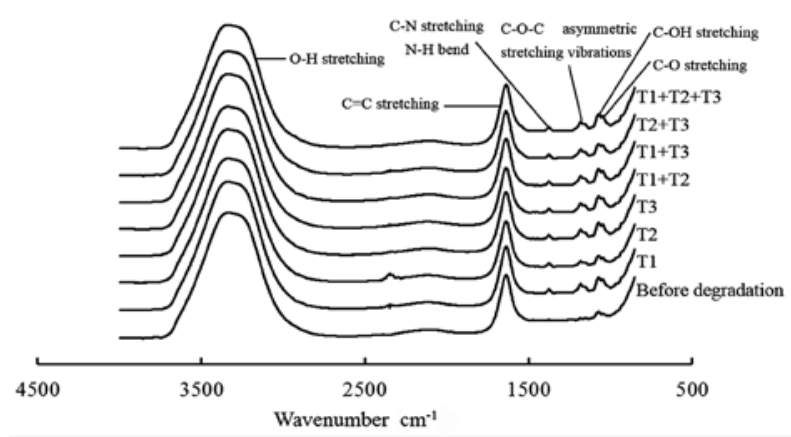

Note. Peaks on curve $\mathrm{T} 1+\mathrm{T} 2+\mathrm{T} 3$ are marked to which functional groups they belong.

Figure 3. Humic acids (HA) infrared (IR) spectroscopy after degradation

The integrated areas of the absorbance peaks of HA before and after degradation were shown in Table 3. For combination treatments, the various treatments resulted in significantly higher absorbance values at 1045, 1075 and $1151 \mathrm{~cm}^{-1}$ than that before degradation, showing $1.65-$ 1.97-, 1.67-1.94- and 3.00-3.20-fold increases. As for single-colony treatments, these compounds in $\mathrm{T} 1$ and $\mathrm{T} 3$ also increased for a large extent, while $\mathrm{T} 2$ showed minimum increases, just with $1.29,1.29$ and 2.00 times than before degradation. These variations suggested that the contents of polysaccharides, alcohols and aliphatic compounds in HA medium increased greatly during bacterial degradation with the exception of $\mathrm{T} 2$, and combined treatments containing $B$. licheniformis (strain 1) showed remarkable increases for these compounds. The $1375 \mathrm{~cm}^{-1}$ absorption peak increased slightly, and this area could reflect $\mathrm{N}$ levels in the medium after degradation. In addition, T1, T1+T2 and $\mathrm{T} 1+\mathrm{T} 3$ containing $B$. licheniformis (strain 1), resulted in relatively lower amounts of aromatic C $\left(1637 \mathrm{~cm}^{-1}\right)$, indicating that this strain might have a relative strong degradation capacity for aromatic $\mathrm{C}$. The absorption peak area at $3340 \mathrm{~cm}^{-1}$ changed less between various treatments and before degradation by comparison, it was due to high levels of hydroxyl groups in the extraction solution.

Amir et al. (2010) reported that the amount of polysaccharides in HA displayed a relative increase after microbial composting, and this research reached the same 
Table 3. Humic acids (HA) relative absorbance peaks spectra

\begin{tabular}{|c|c|c|c|c|c|c|}
\hline \multirow{2}{*}{ Treatment } & $\begin{array}{l}1045 \mathrm{~cm}^{-1} \\
\text { C-O } \\
\text { stretching }\end{array}$ & $\begin{array}{l}1075 \mathrm{~cm}^{-1} \\
\text { C-OH } \\
\text { stretching }\end{array}$ & $\begin{array}{c}1151 \mathrm{~cm}^{-1} \\
\text { C-O-C asymmetric } \\
\text { stretching vibrations }\end{array}$ & $\begin{array}{c}1375 \mathrm{~cm}^{-1} \\
\mathrm{C}-\mathrm{N} \text { stretching, } \\
\mathrm{N}-\mathrm{H} \text { bend }\end{array}$ & $\begin{array}{l}1637 \mathrm{~cm}^{-1} \\
\mathrm{C}=\mathrm{C} \\
\text { stretching }\end{array}$ & $\begin{array}{l}3340 \mathrm{~cm}^{-1} \\
\text { O-H } \\
\text { stretching }\end{array}$ \\
\hline & \multicolumn{6}{|c|}{$\%$} \\
\hline Before degradation & 0.31 & 0.48 & 0.30 & 0.27 & 7.76 & 90.88 \\
\hline T1 & 0.56 & 0.87 & 0.97 & 0.41 & 7.17 & 90.02 \\
\hline $\mathrm{T} 2$ & 0.40 & 0.62 & 0.60 & 0.40 & 7.36 & 90.62 \\
\hline $\mathrm{T} 3$ & 0.58 & 0.90 & 0.93 & 0.46 & 7.39 & 89.74 \\
\hline $\mathrm{T} 1+\mathrm{T} 2$ & 0.59 & 0.92 & 0.96 & 0.45 & 7.27 & 89.81 \\
\hline $\mathrm{T} 1+\mathrm{T} 3$ & 0.58 & 0.90 & 0.95 & 0.43 & 7.18 & 89.96 \\
\hline $\mathrm{T} 2+\mathrm{T} 3$ & 0.51 & 0.80 & 0.90 & 0.44 & 7.23 & 90.12 \\
\hline $\mathrm{T} 1+\mathrm{T} 2+\mathrm{T} 3$ & 0.61 & 0.93 & 0.91 & 0.47 & 7.51 & 89.57 \\
\hline
\end{tabular}

Notes. "C-O stretching" under $1045 \mathrm{~cm}^{-1}$ represents functional group this peak corresponds to. Numbers in the first row, $1045 \mathrm{~cm}{ }^{-1}$, for instance, represent peaks of IR spectroscopy. "\%" is area ratio that a peak area accounts for the total calculated by infrared (IR) spectroscopy.

conclusion. Structural characteristics of HA restricted its degradation (Yanagi et al., 2002; Chistyakov et al., 2013). The HA structures were in the form of aromatic $\mathrm{C}$, aliphatic $\mathrm{C}$ and small-molecule carbohydrates, among these forms, aromatic $\mathrm{C}$ accounted for the largest fraction, and its utilization depended on the degradation capacity of HA-degrading bacteria. Some studies (Filip, Tesařová, 2004; Chistyakov et al., 2013) had shown that the aromatic $\mathrm{C}$ structure of HA exhibited a strong resistance to degradation and was difficult for microbes to use, which agreed with the present study. Moreover, small-molecular aliphatic compounds and polysaccharides accounted for a small fraction and could be easily utilized by HA-degrading microorganisms and, thus, were ideal C sources. The higher the degradation level, the more energy was obtained by the microorganisms from available $\mathrm{C}$ sources, which acted in the next round of degradation and provided energy for HA-degrading microorganisms. Therefore, decomposition level for complex $\mathrm{C}$ compounds can be critical for HA degradation process.

\section{Conclusions}

1. Three strains used for the research could be observed in humic acids (HA) medium which they inoculated. Among the three strains tested, Bacillus licheniformis (strain 1) showed stable growth on HA medium in various combination treatments, with minor variation in its colony-forming units (CFU) being observed. Microbacterium resistens (strain 2) exhibited the poorest growth in the combination treatments, especially in $\mathrm{T} 1+\mathrm{T} 2$ and $\mathrm{T} 1+\mathrm{T} 2+\mathrm{T} 3$, accounting for $25.00 \%$ and $1.94 \%$ of the total CFU, respectively. Treatments involved in Stenotrophomonas maltophilia (strain 3) displayed a relative higher CFU amount (155-260 CFU dish ${ }^{-1}$ ). It could be perceived that these strains could use HA extracted from Heilu soil as sole $\mathrm{C}$ and $\mathrm{N}$ source, while adaptability of them to HA medium varied widely.

2 . The carbon respiration $(\mathrm{CR})$ showed significant differences between various degradation treatments $(P<$ $0.05)$. The CR level in T1 exceeded those of T2 and T3 by $105.69 \%$ and $26.87 \%$, respectively, indicating that strain 1 showed a higher capacity of respiration degradation for HA. Clearly, T1 and T3 showed higher microbial biomass carbon (MBC), illustrating that the two strains possessed a relatively high $\mathrm{C}$ sequestration capacity. Moreover, $\mathrm{C}$ degradation rate was in the range of $18.91 \%$ to $52.05 \%$ for all treatments. These data showed detailed degradation level of HA.

3. Infrared (IR) spectroscopy of HA at the end of the incubation period showed that polysaccharides, alcohols and aliphatic compounds increased in various treatments, with especially evident increases being observed in $\mathrm{T} 1+\mathrm{T} 2$ and $\mathrm{T} 1+\mathrm{T} 2+\mathrm{T} 3$. $\mathrm{T} 1$ exhibited a higher degradation capacity for aromatic $\mathrm{C}$, which displayed in a trend of simplifying the HA structure.

\section{Acknowledgments}

We thank State Key Laboratory of Crop Stress Biology for Arid Areas, Northwest A\&F University, Yangling, China, for their experimental apparatus, and Urumqi Environmental Monitoring Center, Urumqi, China, for technical assistance. Financial support for this research came from the Key Research Program of the Chinese Academy of Sciences (No. KFZD-SW-306).

Received 05072016 Accepted 14112016

\section{References}

Acharya B. S., Rasmussen J., Eriksen J. 2012. Grassland carbon sequestration and emissions following cultivation in a mixed crop rotation. Agriculture Ecosystems and Fnvironment $153(24): 33-39$ https://doi.org/10.1016/j.agee.2012.03.001

Amir S., Jouraiphy A., Meddich A., Gharous M. E., Winterton P., Hafidi M. 2010. Structural study of humic acids during composting of activated sludge-green waste: elemental analysis, FTIR and 13C NMR. Journal of Hazardous Materials 177: 524-529 https://doi.org/10.1016/j.jhazmat.2009.12.064

Badis A., Ferradj1 F. Z., Boucherit A., Fodil D., Boutoumi H. 2010. Removal of natural humic acids by decolorizing actinomycetes isolated from different soils (Algeria) for application in water nurification. Desalination. $259(1-3)$ : 216-222 https://doi.org/10.1016/j.desal.2010.04.001

Baglieri A., Ioppolo A., Nègre M., Gennari M. 2007. A method for isolating soil organic matter after the extraction of humic and filvic acids. Organic Geochemistry, 38 (1): 140-150 https://doi.org/10.1016/j.orggeochem.2006.07.0́07

Chistyakov I. V., 'Irotimov S. Ya., Lysak L. V., Stepanov A. A 2013. Changes in the composition and properties of humic acids under the influence of microorganisms. Moscow Iniversity Soil Science Bulletin 68 (1): 48-52 https://doi.org/10.3103/S0147687413010031

Eaton J. M., Lawrence D. 2009. Loss of carbon sequestration potential after several decades of shifting cultivation in the southern yucatán. Forest Ecology and Management, 258 (6): 949-958 https://doi.org/10.1016/j.foreco.2008.10.019

Filip Z., Kubát J. 2003. Aerobic short-term microbial utilization and degradation of humic acids extracted from soils of long-term field experiments. European Journal of Soil Biology 39 (4): 175-182 https://doi.org/10.1016/S1164-5563(03)00034-7

Filip Z., lesařová M. 2004. Microbial degradation and transformation of humic acids from permanent meadow and forest soils. International Biodeterioration and Bindegradation. 54: 225-231 https://doi.org/10.1016/j.ibiod.2004.06.006

Fu D. L., Liu M. Y., Liu L., Chang Q. R., Zuo J. X., Luo Q. Zhao T. 2014. Decomposition characteristics of soil humic acid under different vegetation types. Research of Environmental Sciences, 27 (5): 513-519 (in Chinese) 
Guo X. J,, Du W., Wang X., Yang Z. F. 2013. Degradation and structure change of humic acids corresponding to water decline in Zoige peatland, Qinghai-Tibet plateau. Science of the Total Fnvironment 445-446: 231-236 https://doi.org/10.1016/j.scitotenv.2012.12.048

Huang H. L., Zeng G. M., Jiang R. Q., Yuan X. Z., Yu M., Huang D. L., Zhang J. C., Feng C. L. 2009. Fluorescence spectroscopy characteristics of humic acid by inoculating white-rot fungus during different phases of agricultural waste composting. Journal of Central South University of Technology. $16(3): 440-443$ https://doi.org/10.1007/s11771-009-0074-7

Huang M. Y., Yang J. F., Lu F. P., Wang H. F. 2007. Microbial properties of artificial soil mixed with brackish dredged sediment, caustic sludge and coal ash. Journal of AgroEnvironment Science, 26 (3): 1159-1163 (in Chinese)

Kontchou C. Y., Blondeau R.1992. Biodegradation of soil humic acids by streptomyces viridosporus. Canadian Journal of Microhiolngy. 38 (3): 203-208 https://doi.org/10.1139/m92-034

Kornıłłowicz-Kowalska 1., Uinalska G., Belcarz A., Iglik H. 2008. Decolorization of humic acids and alkaline lignin derivative by an anamorphic Bjerkandera adusta R59 strain isolated from soil. Polish Journal of Environmental Studies, 17 (6): 903-909

Li Y. P., Yin H., Ye J. S., Peng H., Bai J. Q., He B. Y., Xie D. P., Zhang N. 2012. Effects of exogenous microorganisms on speciations of cadmium and microbial diversity in soil. CIESC Journal, 63 (6): 1850-1858 (in Chinese)

Monib M., Hosny I., Zohdy L., Khalafallah M. 1981. Studies on humic acids decomposing streptomycetes: III. Synthesis of amino acids and organic acids during humic acids decomposition. ZENTRALBLATT für Mikrobiologie, 136 (3). 189-197 (in German) h'ttps://doi.org/10.1016/S0323-6056(81)80016-X

Park H. J., Kim D. 2013. Isolation and characterization of humic substances-degrading bacteria from the subarctic Alaska grasslands. Inurnal of Basic Microhinlngy, 53: 1-8 https://doi.org/10.1002/jobm.201300087

Prentice A. J., Webb E. A. 2010. A comparison of extraction techniques on the stable carbon-isotope composition of soil humic suhstances. Genderma, $155(1-2): 1-9$ https://doi.org/10.1016/j.geoderma.2009.11.015
Ravindran A., Yang S. S. 2015. Effects of vegetation type on microbial biomass carbon and nitrogen in subalpine mountain forest soils. Journal of Microbiology, Immunology and Infection 48 (4): 362-369 https://doi.org/10.1016/j.jmii.2014.02.003

Rinna J., Warning B., Meyers P. A., Brumsack H. J., Rullkötter J. 2002. Combined organic and inorganic geochemical reconstruction of paleodepositional conditions of a Pliocene sapropel from the eastern Mediterranean Sea. Fenchimica Cosmochimica Acta 66 (11) 1 1969-1986 https://doi.org/10.1016/S0016-7037(02)00826-8

Rocker D., Kisand V., Scholzböttcher B., Kneib I., Lemke A., Rullkötter J., Simon M. 2012. Differential decomposition of humic acids by marine and estuarine bacterial communities at varying salinities. Bingenchemistry, 111 (1-3): 331-346 https://doi.org/10.1007/s10533-011-9653-4

Tatzber M., Stemmer M., Spiegel H., Katzlberger C., Haberhauer G., Mentler A., Gerzabek M. H. 2007. FTIRspectroscopic characterization of humic acids and humin fractions obtained by advanced $\mathrm{NaOH}, \mathrm{Na}_{4} \mathrm{P}_{2} \mathrm{O}_{7}$, and $\mathrm{Na}_{2} \mathrm{CO}_{3}$ extraction procedures. Journal of Plant Nutrition and Soil Science, 170 (4): 522-529

Tikhonov V. V., Yakushev A. V., Zavgorodnyaya Yu. A., Byzov B. A., Demin V. V. 2010. Effects of humic acids on the growth of hacteria Furasian Soil Science, 43(3): 305313 https://doi.org/10.1134/S1064229310030087

Yanagi Y., 'lamaki H., Otsuka H., Fujitake N. 2002. Comparison of decolorization by microorganisms of humic acids with different $13 \mathrm{C}$ NMR properties. Soil Biology and Binchemistry, 34 (5): 729-731 https://doi.org/10.1016/S0038-0717(01)00196-1

Yanagi Y., Yoda K., Ogura K., Fujitake N. 2008. Population of humic acid degrading microorganisms in andosols under different vegetation types and grassland management regimens. Microhes and Fnvironments, 23 (1): 44-48 https://doi.org/10.1264/jsme2.23.44

Yim M. H., Joo S. J., Nakane K. 2002. Comparison of field methods for measuring soil respiration: a static alkali absorption method and two dynamic closed chamber methods. Forest Ecology and Management, $170(1-3) \cdot 189-197$ https://dói.org/10.1016/S0378-1127(01)00773-3

ISSN 1392-3196 / e-ISSN 2335-8947

Zemdirbyste-Agriculture, vol. 104, No. 1 (2017), p. 9-14

DOI 10.13080/z-a.2017.104.002

\title{
Bakterijų skaidymo geba iš dirbamos žemès ekstrahuotoms huminèms rūgštims
}

\author{
D. Fu ${ }^{1,2}$, M. Liu ${ }^{1}$, Q. Chang ${ }^{1}$, L. Liu ${ }^{1}$, A. Lv $^{2}$ \\ ${ }^{1}$ Kinijos Šiaurès Vakarų A\&F universiteto Gamtos išteklių ir aplinkos koledžas \\ ${ }^{2}$ Urumqi aplinkos stebėsenos centras, Kinija
}

\section{Santrauka}

Tyrimo tikslas - naudojant tris pasirinkas padermes nustatyti iš dirbamos žemès ekstrahuotų huminių rūgščių skaidymo lygi. Trumpalaikis eksperimentas atliktas 2014 m. Kinijos Šiaurès Rytų A\&F universitete. Iš dirvožemio ekstrahuotos huminès rūgštys panaudotos kaip vienintelis anglies $(\mathrm{C})$ bei azoto $(\mathrm{N})$ šaltinis standžioje mitybinèje terpejje. Tyrimams pasirinktos trys humines rūgštis skaidančios padermès - Bacillus licheniformis (1 padermè), Microbacterium resistens (2 padermè) bei Stenotrophomonas maltophilia (3 padermè), siekiant nustatyti jų individualų ir kompleksinị poveikị anglies skaidymo greičiui ir huminių rūgščiu sudecčiai terpèje. Eksperimentą sudare septyni variantai: T1, T2, T3, T1+T2, T1+T3, T2+T3 ir T1+T2+T3.

Tyrimo rezultatai parodè, kad S. maltophilia (3 padermès) bendras kolonijas formuojančių vienetų skaičius buvo didesnis variantuose, su kuriais ji buvo susijusi. Anglies respiracija ir mikrobu biomasès anglies kiekis ịvairiuose variantuose svyravo atitinkamai nuo 4,04 (T2) iki 12,13 (T2+T3) mg lèkštelèje-1 ir nuo 1,32 (T2) iki 4,96 (T3) $\mathrm{mg}$ lèkštelejje $\mathrm{e}^{-1}$. Tiriant anglies skaidymo huminėse rūgštyse greiti nustatyta, kad anglies respiracijos ir mikrobų biomasès anglies suma sudare tokią tendenciją: T2+T3 (52,05\%)> T1+T3 (49,29\%) > T1 $(44,25 \%)>\mathrm{T} 3$ $(40,61 \%)>\mathrm{T} 1+\mathrm{T} 2(38,39 \%)>\mathrm{T} 1+\mathrm{T} 2+\mathrm{T} 3(37,09 \%)>\mathrm{T} 2(18,91 \%)$. Infraraudonosios spektroskopijos taikymas atskleidè, kad po skaidymo proceso visų variantų terpèse atsirado daugiau angliavandenių, alifatinių komponentų, alkoholių ir azotinių medžiagų. Aromatinès anglies kiekis buvo mažiausias T1 variante, didžiausias $-\mathrm{T} 1+\mathrm{T} 2+\mathrm{T} 3$ variante, palyginus su jos kiekiu prieš skaidymą. Tai rodo, $\mathrm{kad} B$. licheniformis (1 padermė) gali turèti gana stiprią aromatinès anglies skaidymo gebą.

Reikšminiai žodžiai: anglies skaidymo greitis, huminès rūgštys, kolonijas formuojantys vienetai, skaidančios bakterijos, struktūros savybès. 